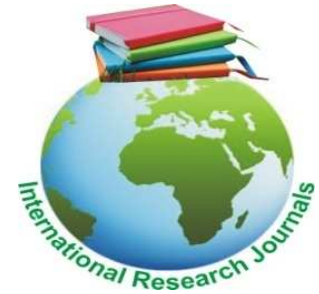

International Research Journal of Agricultural Science and Soil Science (ISSN: 2251-0044) Vol. 7(1) pp. 001-007, February, 2017

DOI: http:/dx.doi.org/10.14303/irjas.2017.013

Available online http://www.interesjournals.org/IRJAS

Copyright (C) 2017 International Research Journals

Full Length Research Paper

\title{
Effect of irrigation quantities and tillage systems on sunflower yield under Khartoum State conditions, Sudan
}

\author{
Abdelmoneim Elamin Mohamed ${ }^{1}$, Adam Bush Adam ${ }^{2^{\star}}$ and Zuhier Yassien Mohamed ${ }^{2}$ \\ ${ }^{1}$ Department of Agricultural Engineering, Faculty of Agriculture, University of Khartoum, Sudan \\ ${ }^{2}$ Department of Agricultural Engineering, Faculty of Natural Resources and Environmental Studies, University of Peace, \\ Sudan \\ *Corresponding Author's E-mail: adambush99@gmail.com
}

\begin{abstract}
The objective of this study was to investigate the response of sunflower (Helianthus annus L.) yield to different irrigation quantities and tillage systems. The experimental work was conducted at the Demonstration Farm of the Faculty of Agriculture, University of Khartoum, Shambat during two different seasons $2011 / 012$ and $2012 / 013$. The treatments were three irrigation quantities $(100 \%, 85 \%$ and $70 \%$ of crop evapotranspiration) and four tillage systems (no till, discing, chiseling and ridging). Split plot experimental design with three replications was used in which the irrigation water amounts were assigned to the main plotsand the different tillage systems to the subplots.The parameters tested were soil physical properties, the vegetative growth and yield.The results indicated that,tillage systems affected clearly soil physical properties; namely bulk density and moisture content. Deep ploughing system decreased the bulk density as compared to no till system. The vegetative growth was significantly $(P \leq 0.05)$ affected by the different irrigation water amounts and tillage systems. Irrigation water amounts of $100 \%$ and $85 \%$ of ETc gave the higher values than $70 \%$ ETc in both seasons. The combination of irrigation water amounts with tillage systems significantly affected the yield. However the combination of no till with $85 \%$ ETc gave the highest yield $(2.3$ ton/fed) in the first season while chiseling with $85 \%$ ETc had the highest yield (1.14 ton/fed) in the second season.
\end{abstract}

Keywords: Irrigation water amounts; Tillage systems; Sunflower Yield

\section{INTRODUCTION}

Irrigation water amounts and tillage systems are important factors, which influence crop yield. Different tillage systems suit different amount of irrigation water. They represent the most costly items in the agricultural budget. Both operations need special management for the different crops, climatic and soil conditions. Tillage treatments directly and indirectly affect bulk density. The direct effect is that soil is pulverized, disturbed and it is volume increased at which the bulk density decreased, while the indirect effect can be found by many passes of heavy machinery over the soil which compact it and it is bulk density increased (Bashour and Sayegh, 2007). Different tillage systems had different effects on soil physical properties such as bulk density, moisture content and penetration resistance (Sessiz et al., 2008). In clay soil there were no differences in crop yield in relation to tillage methods; and the yields were more influenced by the prevailing rainfall and consequent soil moisture content than tillage as stated by Simpson and Gumbs (1992). Banaria et al. (1992) stated that, the decrease of ploughing depth did not influenced wheat and sunflower yields but led to a slightdecrease in maize yield and increased weed infestation.

Sunflower (Helianthus annuus L.) is an important oil crop in the world.In Sudan, the agricultural sector contributes to about $48 \%$ of the Gross Domestic 
Production (GDP) and to about $93 \%$ of the foreign currency earnings. It also employs about $65 \%$ of the labor force (Ministry of Finance and National Economy, 1996).Sunflower is a new edible oil crop and it considered as one of the promising crops recently introduced in Sudan. The seeds have an oil content of 40 - $50 \%$ and $30 \%$ digestible protein and can thus be used as a source of food for humans, or as poultry feed. The crop is sensitive to water stress during the flowering stage.It can be cultivated as winter crop under irrigated conditions and as summer crop under rainfed conditions. Sunflower produced good yields with only 300 to $500 \mathrm{~mm}$ of added water as stated by Weiss (1983).

While Andria et al. (1995) and Perniola (1997) reported that irrigation regimes clearly influenced sunflower seeds yield and it is component. Bashir and Mohamed (2014) investigated the response of two Sunflower hybrids yield to full and deficit irrigationunder semi-arid environment of Gezira, Sudan and obtained that, Seed yield and oil content increased with increasing the amount of irrigation.In Sudan, there were no standard practicesas far as irrigation amounts and tillage systems are concerned which resulted onlow crop productivity and it represents as one of the major problems that are facing agricultural production. Low crop productivity in addition to high production costs, low prices and high taxes had all resulted in a general deterioration of the agricultural sector. This has contributed in converting agriculture from an attractive business to a repellent activity and caused many farmers to abandon agriculture and migrate to cities (Ministry of Finance and National Economy, 1996).

Therefore the main objective of this study was to evaluate the effect of different irrigation water amounts and tillage systems on sunflower yield.

\section{METHODOLOGY}

The experimental work was conducted at the Demonstration Farm of the Faculty of Agriculture, University of Khartoum, Shambat lied at latitude $15^{\circ}$ $14 \square$ and longitude $32^{\circ} 32 \square$ during two different seasons. The first season at winter from 20/10/2011to 8/1/012 and the second season at summer from 15/6/012 to 6/9/013. The treatments were three irrigation water amounts (100\%, $85 \%$ and $70 \%$ of crop evapotranspiration) and four tillage systems. The tillage systems used were:

1. No till (control).

2. Disc plough + harrowing + ridging (conventional).

3. Chisel plough + harrowing +ridging (conservation).

4. Ridging only (minimum).

Split plot experimental design with three replications was used in which the irrigation water amounts were assigned to the main plotsin area of $448 \mathrm{~m}^{2}$ and the different tillage systems to the subplots in $32 \mathrm{~m}^{2}$. All tillage operations were done with a medium size field tractor (Ford 6000).

\section{Characteristics of tillage implements used}

1. Disc plough: fully tractor mounted on three point linkage, standard type with three discs each $66 \mathrm{~cm}$ in diameter and $63 \mathrm{~cm}$ cutting width with $21.3 \mathrm{~cm}$ ploughing depth.

2. Chisel plough: fully tractor mounted on three point linkage with 5 rigid shanks arranged in two rows, three in the front and two in the rear, $142 \mathrm{~cm}$ cutting width with 16 $\mathrm{cm}$ ploughing depth.

3. Disc harrow: fully tractor mounted on three point linkage with 10 discs each $56 \mathrm{~cm}$ in diameter, $180 \mathrm{~cm}$ cutting width with 6.6 ploughing depth.

4. Ridger: fully tractor mounted on three point linkage, lister type with four units, each unit have two wings and shear and spaced at $80 \mathrm{~cm}$.

Irrigation water amounts were calculated according to crop water requirement (ETc). It is generally related to reference evapotranspiration (ETo) which is calculated from meteorological datausing Penman Monteith equation as stated by Smith et al. (1998).

$\mathrm{ET}_{\mathrm{O}}=\frac{0.408 \Delta(R n-G)+\gamma\left(\frac{900}{T}+273\right) U_{2}(e s-e a)}{\Delta+\gamma\left(1+0.34 U_{2}\right)}$

Where:

$\mathrm{ETo}=$ Reference crop evapotranspiration $\left(\mathrm{mm} \mathrm{day}^{-1}\right)$

$\mathrm{R}_{\mathrm{n}}=$ Net radiation at crop surface $\left(\mathrm{Mjm}^{-2} \mathrm{day}^{-1}\right)$

$\mathrm{T}=$ Average temperature at $2 \mathrm{~m}$ height $\left({ }^{\circ} \mathrm{C}\right)$.

$\mathrm{e}_{\mathrm{s}}=\mathrm{Svp}, \mathrm{kPa} \mathrm{e}_{\mathrm{a}}=$ Actual vp $(\mathrm{kPa})$

$\left(e_{s}-e_{a}\right)=$ Saturation pressure deficit for measurement at $2 \mathrm{~m}$ height $(\mathrm{kPa})$.

$\mathrm{U}_{2}=$ Wind speed at $2 \mathrm{~m}$ height $\left(\mathrm{ms}^{-1}\right)$.

$\Delta=$ Slope of vapor pressure curve $\left(\mathrm{kPa}{ }^{\circ} \mathrm{C}\right)$.

$\mathrm{Y}=$ Psychometric constant $\left(\mathrm{k} \mathrm{Pa}^{\circ} \mathrm{C}\right)$

$900=$ Coefficient for reference crop $\left(\mathrm{kj} \mathrm{Kg} \mathrm{day}^{-1}\right)$

$0.34=$ Wind coefficient for the reference crop $\left(\mathrm{sm}^{-1}\right)$

$\mathrm{G}=$ Soil heat flux $\left(\mathrm{Mj} \mathrm{m}^{-2}\right.$ day $\left.^{-1}\right)$

Soil heat flux (G) may be uncounted if the period is less than 10 days which can be calculate according to the equation

$\mathrm{G}_{\text {month }}=0.14\left(\mathrm{~T}_{\text {month }}-\mathrm{T}_{\text {month-1 }}\right) \ldots .$. (2)

Where:

$\mathrm{T}_{\text {month }}=$ Average temperature for the mentioned month $\left({ }^{\circ} \mathrm{C}\right)$

$\mathrm{T}_{\text {month-1 }}=$ Average temperature for the month before $\left({ }^{\circ} \mathrm{C}\right)$

$\mathrm{e}_{\mathrm{a}}=\mathrm{e}_{\mathrm{s}} \times$ relative humidity as a fraction

\section{Wind speed formula}

The following formula was used to adjust the wind speed data from $20 \mathrm{~m}$ to the standard height of $2 \mathrm{~m}$ as stated by Smith et al. (1998). 


$$
\mathrm{U}_{2}=\mathrm{U}_{\mathrm{z}} \quad * \frac{4.85}{\operatorname{Ln}\left(\frac{Z m-0.8}{0.15}\right)} \ldots \ldots \ldots . .(4)
$$

Where:

$\mathrm{U}_{\mathrm{z}}=$ mean wind speed measured at height $(\mathrm{z})(\mathrm{m} / \mathrm{sec})$.

$\mathrm{U}_{2}=$ mean wind speed measured at height $2 \mathrm{~m}(\mathrm{~m} / \mathrm{sec})$.

$\mathrm{Zm}=$ height at which wind speed is measured $(\mathrm{m})$. When there is no enough data to calculate $U_{2}$, it is possible to use the International Average Wind Speed $(1+3) / 2$ $=2 \mathrm{~m} / \mathrm{sec}$.

Irrigation water amounts were measured using a V-notch $90^{\circ}$ weir. The discharge over the weir was calculated using the following equation as stated by Michael (1978).

$\mathrm{Q}=0.0138 \mathrm{H}^{5 / 2}$

Where:

$\mathrm{Q}=$ discharge over the weir in $\mathrm{l} / \mathrm{s}$.

$\mathrm{H}=$ the head over the weir in $\mathrm{cm}$.

Bulk density was measured using the cylinder method (Johnson, 1945) as shown in the following equation:

Bulk density $=\frac{\text { the mass of the clod }}{\text { the volume of the same clod }}$

Moisture content on mass basis was determined using the gravimetric method as stated by Michael (1978) as follows:

$\varnothing \mathrm{d}=\varnothing \mathrm{m} \%{ }^{*} \mathrm{pb}$

Where:

$\varnothing \mathrm{d}=$ moisture content on depth basis $\mathrm{cm} / \mathrm{m}$.

$\varnothing \mathrm{m} \%=$ moisture content on mass basis.

$\mathrm{Pb}=$ bulk density $\mathrm{g} / \mathrm{cm}^{3}$.

Plant height was measured from the soil surface to the tip of the youngest leaf using a metre stick at the 50,70 and 90 days from the planting.

Stem diameter was measured from the soil surface using a vernia at the 70 days from the planting.

Head diameter was measured at the end of the season using a metre stick.

For the plant height, stem diameter and head diameter three tagged plant were taken from each subplot and the means were taken.

Final yield: the harvesting started when signs of maturity were observed, the back of the head turns yellow and brackets turned to brown. The heads were manually cut, dried and threshed. The yield was expressed in ton/fed.

\section{RESULTS AND DISCUSSION}

Table1 shows the mean values of bulk density $\left(\mathrm{g} / \mathrm{cm}^{3}\right)$ and moisture content $(\mathrm{cm} / \mathrm{m})$ for the different tillage systems in the two seasons. Bulk density significantly ( $P$ $\leq 0.05$ ) affected by the different tillage systems. The results showed that chiseling and discing systems the lower bulk density as compared to no till and ridging systems. These may be due to the mixing of the different particle size which resulted in greater pore space and hence decreased the bulk density. Moisture content in the first season showed significantly $(P \leq 0.05)$ difference after the $1^{\text {st }}$ irrigation, while no significant effect after the $7^{\text {th }}$ irrigation due to the different tillage systems. No till system gave the highest moisture depth while chiseling system obtained the lowest values. In the second season the results showed significant $(P \leq 0.05)$ effect in moisture content after the $1^{\text {st }}$ irrigation and $7^{\text {th }}$ irrigation due to tillage systems. No till system gave the highest moisture content as compared to other tillage systems. The higher moisture content under no till system might be attributed to the dominance of micropores and the uncovered fissures in the no till soil profile. These results agreed with the result obtained by Sessiz et al. (2008) who reported that, different tillage systems had different effects on soil physical properties such as bulk density, moisture content and penetration resistance.

Table 2 shows the estimated and actual crop evapotranspiration in the two seasons. The variation between the estimated and actual ETo within the two seasons was found $5 \%$ on the winter season and $7 \%$ on the summer season. These variation may be attributed to the changes in climateconditions at the recent years. While the variations on crop water requirements between summer and winter seasons are due to the differences on seasonal climatic conditions e.g. mean temperature, relative humidity, sunshine, etc. The results agreed with the resultobtained by Adam (2014) who reported that water shortage and water productivity significantly affected by the climate change especially in arid and semi-arid regions.

Table 3 shows the applied water in $\mathrm{m}^{3} / \mathrm{fed} /$ irrigation for the two seasons. The amount of water increased as irrigation decreased up to the $5^{\text {th }}$ irrigation then decreased in final stages of the crop development. These may be due to the changes in the crop factor $(\mathrm{kc})$ which increased during the development stage and decreased at the initial and maturity stages. The total depth of water applied were 631,536 and $442 \mathrm{~mm} / \mathrm{fed}$ at the first and 726.6, 617.6 and $508 \mathrm{~mm} / \mathrm{fed}$ in the second season for the $100 \%, 85 \%$ and $70 \%$ irrigation water amounts, respectively. The use of crop water requirement technique resulted on saving the amount of water applied at the winter season by $13.2 \%$ compared with the summer season. These results are in agreement with the result obtained by Weiss (1983) who reported that, sunflower produced good yields with only 300 to $500 \mathrm{~mm}$ of added water as stated by

Table 4 ( $a$ and $b)$ shows the effect of different irrigation water amounts and tillage systems on plant height $(\mathrm{cm})$, stem diameter $(\mathrm{cm})$, head diameter $(\mathrm{cm})$ and final yield (ton/fed) for the two seasons. Irrigation water amounts were significantly difference $(P \leq 0.5)$ for all parameters. The amounts of $100 \%$ and $85 \%$ ETc gave the higher values as compared to the $70 \%$ ETc. The highest final yield in both seasons was recorded in the $85 \%$ ETc. The reduction on yield and yield component under $70 \%$ ETc might be attributed to the fact that $70 \%$ 
004 Int. Res. J. Agric. Sci. Soil Sci.

Table 1. Effect of different tillage systems on bulk density $\mathrm{g} / \mathrm{cm}^{3}$ and moisture content $\mathrm{cm} / \mathrm{m}$ after three days from $1^{\text {st }}$ and $7^{\text {th }}$ irrigation for two seasons

\begin{tabular}{lcccccc}
\hline Parameter & season & No till & Discing & Chiseling & ridging & SE \pm \\
\hline Bulk density & $2011 / 012$ & $1.47^{\mathrm{a}}$ & $1.31^{\mathrm{b}}$ & $1.25^{\mathrm{b}}$ & $1.46^{\mathrm{a}}$ & 0.018 \\
$\varnothing \mathrm{d} 1^{\mathrm{st}}$ moisture & " & $13.35^{\mathrm{a}}$ & $12.95^{\mathrm{ab}}$ & $11.68^{\mathrm{b}}$ & $12.00^{\mathrm{ab}}$ & 0.37 \\
$\varnothing \mathrm{d} 7^{\text {th }}$ moisture & " & 21.58 & 18.98 & 18.33 & 18.75 & $\mathrm{~ns}$ \\
Bulk density & $012 / 013$ & $1.34^{\mathrm{a}}$ & $1.28^{\mathrm{b}}$ & $1.21^{\mathrm{c}}$ & $1.30^{\mathrm{b}}$ & 0.01 \\
$\varnothing \mathrm{d} 1^{\mathrm{st}}$ moisture & " & $28.15^{\mathrm{a}}$ & $22.45^{\mathrm{bc}}$ & $19.98^{\mathrm{c}}$ & $25.03^{\mathrm{ab}}$ & 0.11 \\
$\varnothing \mathrm{d} 7^{\text {th }}$ moisture & " & $27.98^{\mathrm{a}}$ & $23.98^{\mathrm{ab}}$ & $21.20^{\mathrm{ab}}$ & $18.53^{\mathrm{b}}$ & 1.59 \\
\hline
\end{tabular}

Means with the same letter (s) within a row are not significantly differences at $(P \leq 0.05)$ according to DMRT

Table 2. The estimated and actual ETo using Penman Monteith equation as stated by Smith et al .(1998) and histological metrological data (2005 to 2010) for the 2011/012 and $012 / 013$

\begin{tabular}{llll}
\hline Month & Season & Estimated ETo mm/day & Actual ETo mm/day \\
\hline October & $2011 / 012$ & 6.8 & 7.4 \\
November & & 7.3 & 6.6 \\
December & & 6.2 & 5.8 \\
January & & 6.1 & 5.4 \\
Mean & 6.6 & 6.3 \\
June & $012 / 013$ & 7.7 & 7.9 \\
July & & 8.2 & 9.1 \\
August & & 7.1 & 8.1 \\
September & & 8.6 & 8.7 \\
Mean & 7.9 & 8.45 \\
\hline
\end{tabular}

Table 3. The applied water in $\mathrm{m}^{3} / \mathrm{fed} /$ irrigation for each irrigation water amount for the two seasons 2011/012 and $012 / 013$

\begin{tabular}{|c|c|c|c|c|c|c|c|c|c|}
\hline \multirow{2}{*}{\multicolumn{2}{|c|}{ Irrigation amount }} & \multicolumn{8}{|c|}{ Amounts of water applied in $\mathrm{m}^{3} / \mathrm{fed} /$ irrigation } \\
\hline & & $1^{\text {st }}$ & $2^{\text {nd }}$ & $3^{\text {rd }}$ & $4^{\text {th }}$ & $5^{\text {th }}$ & $6^{\text {th }}$ & $7^{\text {th }}$ & Total \\
\hline $100 \%$ ETc & $2011 / 012$ & “ & 113.4 & 239.9 & 595.2 & 672.4 & 625 & 402.9 & 2648.8 \\
\hline $85 \%$ ETc & & “ & 96.4 & 203.9 & 505.9 & 511.5 & 631.3 & 342.5 & 2251.5 \\
\hline $70 \%$ ETc & & “ & 79.4 & 167.9 & 416.6 & 470.7 & 437.5 & 282 & 1854.2 \\
\hline $100 \%$ ETc & $012 / 013$ & “ & 129.4 & 264.7 & 669.1 & 810.7 & 715.7 & 462.2 & 3051.8 \\
\hline $85 \%$ ETc & & “ & 111.0 & 225.7 & 568.7 & 689.1 & 608.4 & 392.9 & 2594 \\
\hline $70 \%$ ETc & & “ & 90.6 & 185.3 & 468.4 & 567.5 & 501.0 & 323.5 & 2136.3 \\
\hline
\end{tabular}

ETc was not enough for sunflower crop, this shortage of crop water requirement had led to water stress which resulted on the reduction in final yield and yield components values. The results agreed with the result obtained by Bashir and Mohamed (2014) who studied the response of two Sunflower hybrids yield to full and deficit irrigation under semi-arid environment of Gezira, Sudan and obtained that, Seed yield and oil content increased with increasing the amount of irrigation.

Effect of tillage systems was inconsistent in both seasons. In the first season no till and ridging systems obtained the higher values as compared to other tillage systems. These results may be attributed to the treason that sun flower crop is a tap rooted crop and not effected 
Table 4.a. Effect of different irrigation water amounts and tillage systems on plant height $(\mathrm{cm})$, stem (cm), head diameter $(\mathrm{cm})$ and final yield (ton/fed) for season 2011/012

\begin{tabular}{|c|c|c|c|c|c|c|}
\hline \multirow[t]{2}{*}{ Parameters } & \multirow[t]{2}{*}{ Tillage systems } & \multicolumn{4}{|c|}{ Irrigation water amounts } & \multirow[b]{2}{*}{ SE士 till. } \\
\hline & & $100 \% E T c$ & $85 \%$ ETc & $70 \% E T c$ & Mean & \\
\hline \multirow{9}{*}{$\begin{array}{l}\text { Plant height at } 50 \text { days } \\
\text { from planting }\end{array}$} & No till & 114.06 & 160.23 & 144.58 & $139.61^{a}$ & \multirow{5}{*}{5.77} \\
\hline & Discing & 132.89 & 179.22 & 135.45 & $149.18^{a}$ & \\
\hline & Chiseling & 126.00 & 151.53 & 140.00 & $139.15^{\mathrm{a}}$ & \\
\hline & Ridging & 138.89 & 174.45 & 139.11 & $139.15^{\mathrm{a}}$ & \\
\hline & Mean & $138.89^{b}$ & $174.45^{\mathrm{a}}$ & $139.11^{\mathrm{ab}}$ & 144.67 & \\
\hline & SE \pm irrig. & & & 5.14 & & \multirow{9}{*}{2.61} \\
\hline & $\mathrm{SE} \pm$ inter. & & & 10.29 & & \\
\hline & No till & 162.78 & 201.68 & 174.22 & $179.56^{\mathrm{ab}}$ & \\
\hline & Discing & 182.81 & 196.89 & 170.22 & $183.31^{\mathrm{a}}$ & \\
\hline \multirow{7}{*}{$\begin{array}{l}\text { Plant height at } 70 \text { days } \\
\text { from planting }\end{array}$} & Chiseling & 156.78 & 191.50 & 165.44 & $171.24^{b}$ & \\
\hline & Ridging & 184.53 & 207.67 & 159.11 & $183.77^{\mathrm{a}}$ & \\
\hline & Mean & $171.73^{\mathrm{b}}$ & $199.43^{\mathrm{a}}$ & $167.25^{b}$ & 179.47 & \\
\hline & SE \pm irrig. & & & 3.22 & & \\
\hline & SE \pm inter. & & & 6.43 & & \\
\hline & No till & 195.89 & 215.00 & 185.00 & 198.80 & \multirow{5}{*}{2.05} \\
\hline & Discing & 204.33 & 223.94 & 177.00 & 201.76 & \\
\hline \multirow{7}{*}{$\begin{array}{l}\text { Plant height at } 90 \text { days } \\
\text { from planting }\end{array}$} & Chiseling & 190.98 & 211.67 & 176.17 & 192.94 & \\
\hline & Ridging & 104.90 & 224.83 & 174.28 & 201.34 & \\
\hline & Mean & $199.03^{a b}$ & $218.99^{a}$ & $178.11^{b}$ & 198.71 & \\
\hline & $\mathrm{SE} \pm$ irrig. & & & 3.84 & & \multirow{9}{*}{0.10} \\
\hline & SE \pm inter. & & & 7.67 & & \\
\hline & No till & 3.68 & 3.58 & 2.58 & 3.28 & \\
\hline & Discing & 3.27 & 3.28 & 2.58 & 3.04 & \\
\hline \multirow[t]{7}{*}{ Stem diameter } & Chiseling & 3.97 & 3.47 & 2.31 & 3.25 & \\
\hline & Ridging & 3.88 & 3.19 & 2.20 & 3.09 & \\
\hline & Mean & $3.70^{\mathrm{a}}$ & $3.38^{a}$ & $2.42^{b}$ & 3.16 & \\
\hline & SE \pm irrig. & & & 0.09 & & \\
\hline & $\mathrm{SE} \pm$ inter. & & & 0.18 & & \\
\hline & No till & 21.86 & 23.78 & 17.87 & $21.17^{\mathrm{a}}$ & \multirow{5}{*}{0.20} \\
\hline & Discing & 21.53 & 19.04 & 18.10 & $19.57^{b}$ & \\
\hline \multirow[t]{7}{*}{ Head diameter } & Chiseling & 21.17 & 19.60 & 16.38 & $19.38^{b}$ & \\
\hline & Ridging & 22.86 & 20.90 & 17.43 & $20.40^{\mathrm{ab}}$ & \\
\hline & Mean & $22.11^{\mathrm{a}}$ & $21.83^{\mathrm{ab}}$ & $17.45^{\mathrm{b}}$ & 20.13 & \\
\hline & SE \pm irrig. & & & 0.72 & & \multirow{9}{*}{0.11} \\
\hline & $\mathrm{SE} \pm$ inter. & & & 0.43 & & \\
\hline & No till & 1.71 & 2.26 & 1.26 & 1.74 & \\
\hline & Discing & 1.73 & 1.36 & 1.28 & 1.46 & \\
\hline \multirow[t]{5}{*}{ Final yield } & Chiseling & 1.78 & 1.57 & 0.96 & 1.44 & \\
\hline & Ridging & 1.56 & 1.78 & 1.34 & 1.56 & \\
\hline & Mean & $1.70^{\mathrm{a}}$ & $1.74^{\mathrm{a}}$ & $1.21^{b}$ & 1.55 & \\
\hline & SE \pm irrig. & & & 0.08 & & \\
\hline & $S E \pm$ inter. & & & 0.16 & & \\
\hline
\end{tabular}

Means followed by the same letter (s) within a column are not significantly different at $P \leq 0.05$ according to DMRT

by tillage action to penetrate the soil layers under the none problematic soils which have no hard pans, also the soils under no till system and minimum tillage system were found with a highly moisture content compared to with deep ploughing systems. The results agreed with the result obtained by Simpson and Gumbs (1992). 
006 Int. Res. J. Agric. Sci. Soil Sci.

Table 4.b. Effect of different irrigation water amounts and tillage systems on plant height $(\mathrm{cm})$, stem diameter $(\mathrm{cm})$, head diameter $(\mathrm{cm})$ and final yield (ton/fed) for season 2012/013

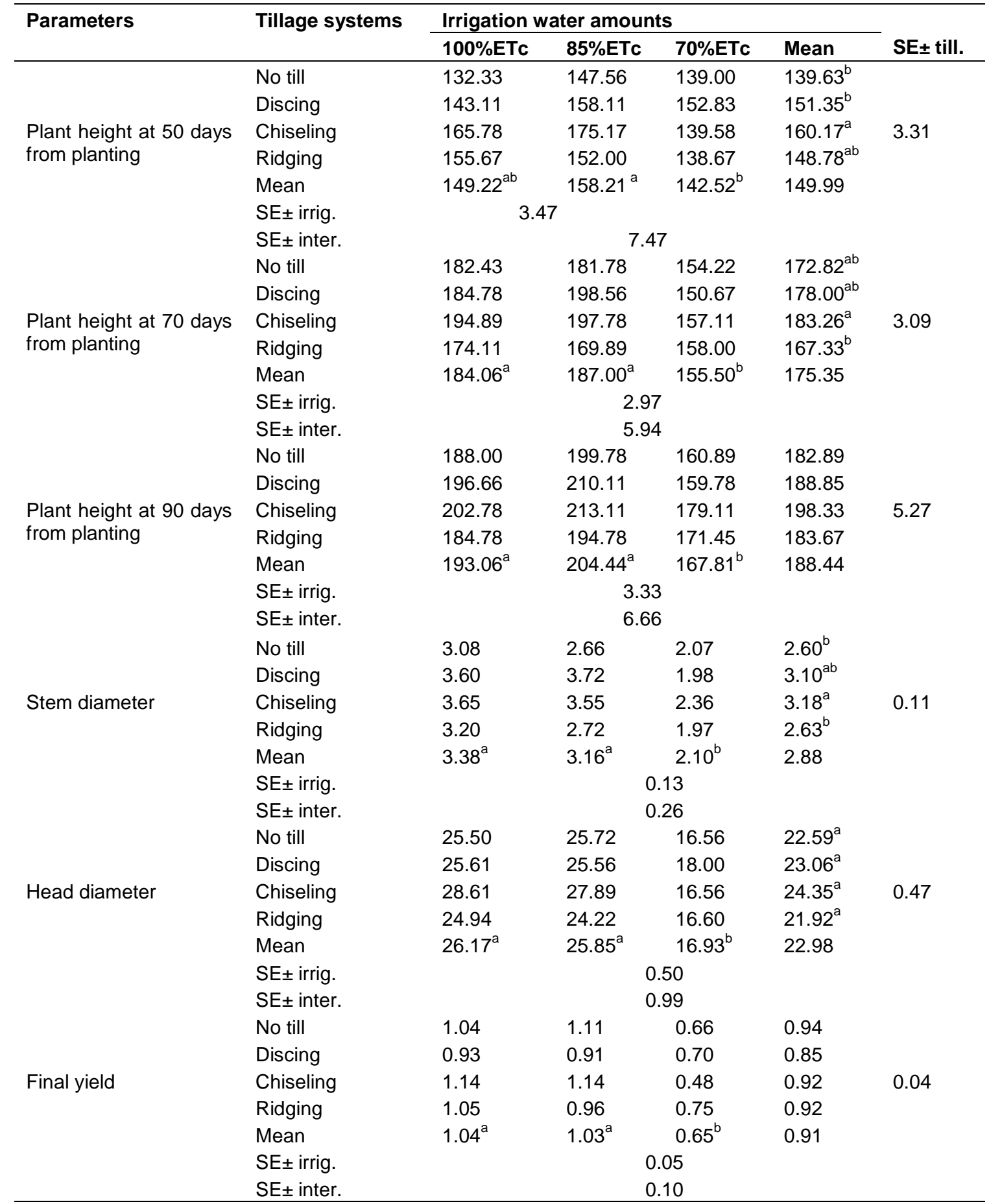

Means followed by the same letter (s) within a column are not significantly different at $\mathrm{P} \leq 0.05$ according to DMRT

In the second season chiseling and discing systems gave the higher values of plant height, stem diameter and final yield. This may be due to the improvement of moisture status and good control of weeds under the deep ploughing systems that led to good crop stand.

Differences due to interactions among tillage systems 
and irrigation quantities were shown in both seasons. The results showed that there was significant effect of tillage systems and irrigation quantities on sunflower seed yield and plant heightwith the exception of those in head diameter. However, the highest seed yield was obtained by the combination of tillage system chisel plough + harrowing +ridging (conservation) with 100\% ETc irrigation quantities. This may be due to more uniformity of water distribution in that plot and improvement of soil aeration conditions as stated by Guirgius et al. (2015).

\section{CONCLUSION}

Irrigation water amounts represent the main factor that affects sunflower yield than tillage systems. Since the crop was found more sensitive to water regimes than tillage systems. The results showed the possibility of reducing the cost of sunflower production by reducing tillage operations and using crop water requirement techniques.

\section{REFERENCES}

Adam HS (2014). Agroclimatology, Crop Water Requirement and Water Management. Water Management and Irrigation Institute, University of Gezira Book. $2^{\text {nd }}$ Edition. University of Gezira Press.

Andria R, Chiaranda FQ, Magliulo V, Mori M (1995). Yield and soil water uptake of sunflower sown in spring and summer. Agron. J. 87: 1122-1128.

Banaria E, Mazzoncin M, Mosoni A, Bertolocci M, Perioli R (1992). Yield response of sugarbeet (Beta vulgaris L.), sunflower (Helianthus annus L.), soybean (Cilycine maz L.) and corn (Zea maze L.) under different irrigation regimes. Central Italy. Rivista di Agronomy (Italy) Oct. - Dec. 26: 676-684.

Bashir MA, Mohamed Y (2014). Evaluation of full and deficit irrigation on two Sunflower hybrids under semi-arid environment of Gezira, Sudan. Journal of Agric.Food and Applied Sciences 2:53-59.
Bashour II, Sayegh AH (2007). Measurement of bulk density. Method of analysis for soils of arid and semi-arid regions. Food and Agric. Organization of the United Nations, Rome.

Guirgius AE, Aboukarima AM, Elmarazky MS, Egela MI (2015). Sunflower crop response to furrow irrigation inflow rate and tillage system. Misr J. Agric. Eng., 25(1): 38-57.

Johnson JR (1945). An accurate method for determining vol. of soil clod. J. of soil sci. 59:449-453.

Michael AM (1978). Irrigation theory and practices. VIKAS Publishing House. LTD Newdelhe.

Ministry of Finance and National Economy (1996) .The economic overview, Sudan Government, Khartoum.

Perniola M, Ratelli AR (1997). Irrigation regimes and sowing date effect on some sunflower cultivators in three areas of Basiclicata irrigation dranaggio (Italy) 44(1):17-52

Sessiz A, Sogut T, Alp A, Esgici R (2008). Tillage effects on sunflower (Helianthus annuus, L.) emergence, yield, quality and fuel consumption in double cropping system. J. Central European Agriculture. 9:(4) 697-710.

Simpson LA, Gumbs FA (1992). Effect of continued cropping on a heavy clay soil on the cost of operations with and without tillage. $J$. of Tropical Agriculture 69(2):111-118.

Smith MG, Allan JL, Monteith A, Perrier L, Sergen A (1998). Report of the Expert Consultation on Procedures for Revision of FAO Guidelines for prediction of Crop Water Requirement UN FAO, Rome, Italy, Pp 56.

Weiss EA (1983). Oil seed crops. Published in the USA Longmans Inc. Pp. 404-462 New York. 